\title{
A Database for John Locke's Medical Notebooks and Medical Reading
}

\author{
G G MEYNELL*
}

John Locke was born in 1632 and died in 1704, and devoted his working life to a remarkably wide range of interests, quite apart from the philosophical studies for which he is generally remembered. They included such topics as education, the national coinage, colonial administration and, not least, the life-long study of medicine. Indeed, Locke's interest in medicine was so strong that it was not until he was about thirty years old that he finally decided against a medical career because of poor health. ${ }^{1}$ All Locke's medical knowledge appears to have come from books and from his acquaintance. He entered Christ Church Oxford in 1652 and graduated MA in 1658 but never had any formal medical training and only occasional clinical experience. ${ }^{2}$ In other words, for all his intelligence and interest in the subject, Locke appears to have remained an educated amateur in medicine. His attempts in 1666 and 1670 to be awarded an Oxford medical degree were blocked by opposition within the university and it was not until 6 February 1675 that he was given a BM (though never a DM). ${ }^{3}$ Nevertheless, he made notes on patients from time to time; ${ }^{4}$ and, throughout his life, he continued to buy books on medical topics, as can be seen from Figure 1.

* G G Meynell, Haven House, Granville Road, St Margaret's Bay, Dover, Kent CT15 6DR.

${ }^{1}$ For Locke's decision not to enter on a medical career, see Locke to Herbert, 28 Nov./8 Dec. 1684. Letter 797 in The correspondence of John Locke, ed. E S de Beer, 8 vols, Oxford, Clarendon Press, 1976-, vol. 2, pp. 661-6. Lady Masham to Jean Le Clerc, 12 January 1704. Amsterdam University Library, MS. J.57.a. Reprinted in full by R Colie, History of Ideas News Letter, 1955, 1: pt. 4, pp. 13-18; 2 , pp. 9-11, 35-7, 818; and in part by H R F Bourne, The life of John Locke, 2 vols, London, Henry S King, 1876, vol. 1, p. 197.

For Locke's medical interests at Oxford, see $\mathrm{K}$ Dewhurst, 'An Oxford medical student's notebook', Ox. med. Sch. Gaz., 1959, 11: 141-5; and idem, 'An Oxford medical quartet: Sydenham, Willis, Locke and Lower', in Oxford medicine: essays on the evolution of the Oxford Clinical School to commemorate the bicentenary of the Radcliffe Infirmary, 1770-1870, ed. K Dewhurst, Oxford, Sandford Publications, 1970. Further details are in Dewhurst's books: John Locke (1632-1704), physician and philosopher: a medical biography, London, Wellcome Historical Medical Library, 1963; Dr. Thomas Sydenham (1624-1689): his life and original writings, London, Wellcome Historical Medical Library, 1966; and Thomas Willis's Oxford lectures, Oxford, Sandford Publications, 1980.

${ }^{3}$ For the archival sources for Locke's BM, see Dewhurst (1963), op. cit., note 2 above, p. 49n. General accounts of Locke at Oxford are in Bourne, op. cit., note 1 above, vol. 1, pp. 26-194; M Cranston, John Locke: a biography, London and New York, Longmans, Green \& Co., 1957, pp. 29-104; P Laslett, John Locke. Two treatises of government. A critical edition with an introduction and apparatus criticus, Cambridge University Press, 1960; amended edition, 1964, pp. 58, 74, 130-45; P Abrams, John Locke. Two tracts on government. Edited with an introduction, notes and translation, Cambridge University Press, 1967, pp. 247-9;

$\mathrm{J} L$ Axtell, The educational writings of John Locke, Cambridge University Press, 1968, pp. 27-44;

$\mathrm{H}$ Kearney, Scholars and gentlemen: universities and society in pre-industrial Britain, 1500-1700, London, Faber \& Faber, 1970, pp. 146-8, 164-5; and J R Milton, 'Locke at Oxford', in G A J Rogers (ed.), Locke's philosophy: content and context, Oxford, Clarendon Press, 1994.

${ }^{4}$ Two famous patients were Lord Ashley, seen by Locke, Sydenham, Glisson and others in 1668 , whose hydatid cyst was only diagnosed by Osler in 


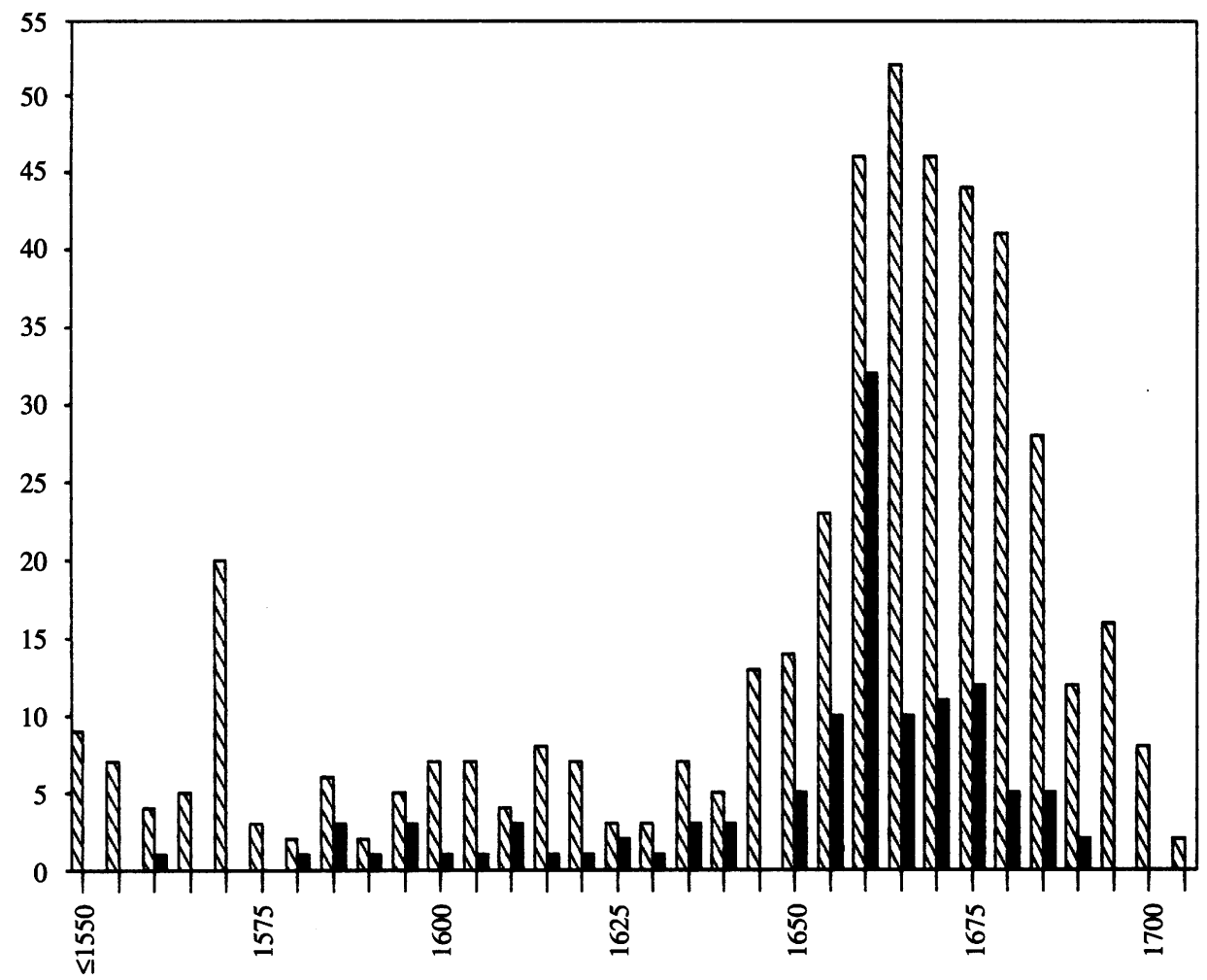

Figure 1: The dates of 578 books in Locke's library catalogue classified here as "medical" or "chemical" (indicated by cross-hatched and solid bars, respectively). Showing the number of titles in each 5 year period ending at the year shown on the abscissa. The peak of medical books in $1565-70$ is due to Locke making a separate entry for each of the thirteen parts of Estienne's Medicae artis principes (Paris, 1567). Supposing Locke to have decided against a medical career in 1662 , then between 1663 and his death in 1704, he must nevertheless have bought at least 230 medical, and 34 chemical, books dated 1663 onwards ( $46 \%$ of the total).

1900; and the Countess of Northumberland who suffered from trigeminal neuralgia in December 1677. A series of cases seen in September 1667 to May 1670 is in British Library Add. MS. 5,714 and has been published by Withington and by Dempster. Individuals seen between January 1677 and September 1679 include Mr Herbert, Mrs Sandys, Mr Robinson, and "C.B." [Caleb Banks]. All these are indexed by Dewhurst (1963), op. cit., note 2 above; and by G G Meynell, Materials for $a$ biography of Dr. Thomas Sydenham (1624-1689). $A$ new survey of public and private archives, Folkestone, Winterdown Books, 1988; and idem,

\author{
A bibliography of Dr. Thomas Sydenham \\ (1624-1689), Folkestone, Winterdown Books, 1990, \\ pp. 142-61. Locke's medical notes often show \\ innovations in method, such as the symbols he \\ placed in the margins and the condensed notation for \\ daily observations which he used for 14 cases of \\ measles in February 1670 (MS. d.9, pp. 176-81. \\ G G Meynell, 'John Locke's method of common- \\ placing, as seen in his drafts and his medical \\ notebooks, Bodleian MSS. Locke d.9, f.21 and f.23', \\ The Seventeenth Century, 1993, 8: 245-67; \\ Appendix I).
}




\section{A Database for John Locke's Medical Notebooks}

Locke's personal library was substantial and included over 400 titles of medical and scientific interest, as became evident in 1965 after publication of its catalogue, edited by Harrison and Laslett. ${ }^{5}$ While he went through a book, he made notes in one of a series of notebooks, comprising common-place books and diaries, which were catalogued in 1959.6 Yet, despite the volume of work published on Locke in recent years, no systematic examination of these notebooks seems to have been made in order to see which of his books Locke actually used, as distinct from merely owning. Clearly, he was unlikely to have been influenced by a book he had never read. The main object here, therefore, is to identify which books Locke mentions in his medical notebooks, together with their location and other details, notably his indexes. When Locke read a book, he often indexed its contents. Such indexes have been neglected although they show which pages caught Locke's attention and, no less interesting, which he passed over. For example, his index to Sydenham's Observationes medicae (London, 1676. HL.2814) entirely omits any reference to the Preface, generally regarded as one of the most important chapters Sydenham ever wrote. The explanation may lie in the known association between the two men. ${ }^{7}$

The library catalogue alone showed that the present study would include several hundred titles at the very least. ${ }^{8}$ To render this number manageable, a database was set up with a separate record for each book. ${ }^{9}$ The collection of records could then be sorted almost instantaneously according to criteria chosen at will and used either singly or in combination. A simple example is whether a book is mentioned in a particular notebook. It is equally possible to select or ignore all books whose titles include a string like "med" or "sal", or to select using multiple criteria. For example, to select only those medical

\footnotetext{
$5 \mathrm{~J}$ Harrison and P Laslett, The library of John Locke, 1st ed., Oxford University Press for the Oxford Bibliographical Society, 1965; 2nd ed., Oxford, Clarendon Press, 1971. Books which belonged to Locke are referred to here by their catalogue number (e.g. HL.3197); otherwise, the title and imprint are given.

${ }^{6} \mathrm{P}$ Long, A summary catalogue of the Lovelace collection of the papers of John Locke in the Bodleian Library, Oxford University Press, 1959, and idem, 'The Mellon donation of additional manuscripts of John Locke from the Lovelace Collection', Bodleian Libr. Rec., 1962-67, 7: 185-93; Meynell (1988), op. cit., note 4 above, \$9, pp. 31-40. The common-place books and diaries are here referred to collectively as "notebooks" and their shelf-marks are abbreviated, e.g. from "Bodleian MS. Locke d.9" to "MS. d.9."

${ }^{7} \mathrm{G}$ Meynell, 'Locke's collaboration with Sydenham: the significance of Locke's indexes', The Locke Newsletter, 1996, no. 27, pp. 65-74.

${ }^{8}$ The catalogue has 3,641 titles of which an unspecified $401(11.1 \%)$ were classed as "medical" (Harrison and Laslett (1965), op. cit., note 5 above, p. 18. The 2nd ed. includes an index with a more detailed classification of the books with separate entries for, e.g., anatomy, modern medicine and physiology).
}

\begin{abstract}
${ }^{9}$ A copy of the database is available for general use in the Wellcome Institute for the History of Medicine and may be copied, but it needs to be used with discretion as a preliminary draft of data that are often incomplete. Originally, the database was used as a convenient finding aid and notepad, and it still shows its origins. In general, the difficulties arise partly because Locke's notes often lack an essential detail and partly because he often used different editions of the same title, which may simply be pirated reprints. It is best used for tracing an author or the contents of a particular notebook. Other details can be retrieved like dates of successive editions but they are always part of a single record and do not have separate fields. The records also show whether the text of a book is copied or if it is mentioned by title only; if it has an index; and if it was bought, bound or lent. Any or all of these can be selected. The database is almost certainly far from complete but it should provide a convenient point of departure in examining the notebooks. An accompanying file, DETAIl.ASC, describes the fields and other conventions in detail. Other files include the database as originally created by LotusWorks ver.1. This uses the same file structure as other databases such as dBASE II Plus in which it can be used immediately. An exported delimited Ascil file is also present which can be imported into other databases as necessary (and which, incidentally, can also be read by most wordprocessors).
\end{abstract}




\section{G G Meynell}

books published in 1608-54 in Paris and to arrange them either first by author and then by date of imprint, or vice versa; or to compare the number of books Locke owned which had been published in Paris or Montpellier at various dates. There are innumerable possibilities.

\section{Interpretation of the Notebooks}

The arrangement of the notebooks is usually easy to follow, thanks to Locke's meticulous habits, provided the principles of his system and various abbreviations are understood. ${ }^{10}$ In general, the entries follow his method of common-placing with a keyword in the left margin, the entry proper and finally, the source. Some entries are in shorthand, including most of MS. f.21. They can nevertheless be followed because Locke left significant words in longhand, apparently to help him understand his notes. ${ }^{11}$

Successive entries vary enormously in importance. One might simply be a remedy suggested by a friend or a member of his family like Agnes Locke. Or it might be concerned with a medical or scientific question and have come directly from a man like Boyle, Sydenham, Lower, Thomas, Schard or Slade. ${ }^{12}$ A few entries, not surprisingly for the time, concern the care of animals, as in "A horse that will not stand still to be shoed, knock gently with a hammer on his forehead . .." ${ }^{13}$ A curious category has judgements on other authors copied from whichever book Locke was reading, such as "Ent. Learned philosopher \& physitian. Castle Chym. Galen. p.116 67". ${ }^{14}$ There are many medical "receipts" or prescriptions of the kind so often found in common-place books which today may seem trite or even bizarre. ${ }^{15}$ But such entries are not to be written off lightly for they are a record of folk medicine or general experience written down at a time when no one knew what was important and what was not. These notes, and those Locke took from descriptions of foreign travels, are to be regarded as "histories" in the sense used by Bacon and by the Royal Society. ${ }^{16}$ They are notes on everything imaginable: cures, techniques, morals, religion, food, the swaddling of babies, and any sort of detail that might one day be useful.

${ }^{10}$ Meynell (1993), op. cit., note 4 above.

${ }^{11} \mathrm{G}$ Meynell, 'The function of longhand in Locke's shorthand', Bodleian Libr. Rec., 1991-94, 14: $340-2$. Both the longhand and shorthand versions of the same passage are shown in Figure 2 of G G Meynell, Thomas Sydenham's Observationes medicae (London, 1676) and his Medical observations (Manuscript 572 of the Royal College of Physicians of London). With new transcripts of related Locke MSS. in the Bodleian Library, Folkestone, Winterdown Books, 1991.

12 For entries due to Boyle, see G G Meynell, 'Locke, Boyle and Peter Stahl', Notes Rec. R. Soc. London, 1995, 49: 185-92, note 2. Those due to Sydenham are signed " $F$ ". The others include Richard Lower, the physiologist; David Thomas, physician and a friend of long standing; J Schard, a German chemist Locke met in 1665 and with whom he corresponded; and Matthew Slade, a Dutch physician who wrote a poem in praise of Sydenham
(K Dewhurst, 'Some verses in honour of Dr. Thomas Sydenham', Janus, 1962, 50: 193-7).

${ }^{13} \mathrm{~K}$ Dewhurst, 'Some 17 th-century veterinary notes from the journals of John Locke (1632-1704)', Vet. Rec., 1962, 74: 996-9.

${ }^{14}$ Many similar judgements occur in Brit. Lib. Add. MS. 32,554 and in MS. f.14.

${ }^{15}$ Boyle's Medicinal experiments (London, Smith, 1692) contain little else. See also the heading 'Receipts' in E J L Scott, Index to the Sloane manuscripts in the British Museum, London, British Museum, 1904; repr. 1971, pp. 446-7. Three of the most valuable drugs known to medicine were derived from popular experience, namely, morphia, digitalis and salicylic acid.

${ }^{16} \mathrm{~F}$ Bacon, De dignitate et augmentis scientiarum, Bk II, ch. 2. L Rook[e], 'Directions for sea-men, bound for far voyages', Phil. Trans., 1666, 1: 140-1; R Boyle, 'General heads for a natural history of a countrey, great or small, ...', ibid., pp. 186-9. 


\section{A Database for John Locke's Medical Notebooks}

Occasional entries are marked by an unusual symbol printed here as "C:" which resembles a capital $\mathrm{C}$ enclosing three dots or, on one occasion, a minute " 3 ". It evidently signified "from", as in the entry "Ld. Brooke of Episcopy. C:Milton Ariopatica [!] p.35". ${ }^{17}$ Examples are "C:Ward" (possibly Isaiah Ward of Christ Church), "C:Iv." (Dr Ivie, a family friend) or "C:Stub", often given as "C:S", who was Henry Stubbe, exWestminster School and Christ Church like Locke, physician, classicist and UnderLibrarian of the Bodleian (1657).

Other notes are marked "Barlo". This was Thomas Barlow, the distinguished Oxford academic who, amongst other appointments, became Bodley's Librarian (1652) and who prepared a reading list for young men which was widely used by Oxford students, including Locke's own pupils. ${ }^{18}$

These entries bring out a recurring feature of Locke's notes: those taken from another author invariably appear to be not paraphrases of the originals but straightforward copies. When Locke quotes "Barlo", his entries have the same order as in Barlow's manuscript and repeat Barlow's comments word for word as in the entry, "Stephanus", "extreame scarce \& very deare". ${ }^{19}$ Similarly, a single entry of Locke's may cover several pages of a notebook, as with Andreas Cellarius, Harmonia macrocosmica (Amsterdam, Jansson, 1661) in MS. f.25 or may consist of a few words only as in the column of short quotations headed 'Cerebrum' in MS. d.11, CEe, which all come from Wepfer's Observationes anatomicae ... apoplexia (HL.3135). In each case, the entry is copied from the original.

In the fully-developed form of Locke's method of common-placing, the source of an entry is easy to determine, as in the reference from George Castle's The chymical Galenist, 1667, mentioned above. But elsewhere the source may be less obvious. The bare reference "Barlo" is identifiable because his name is associated with only one title. Unfortunately, this is not the case with many medical authors whom Locke might quote simply as "Hippo", "Holl" or "Ent". When he did add more detail, he often picked out from the title only the words he considered significant. An instance that occurs frequently is "Paulli botan . . . 67" which is Paulli's Quadripartitum botanicum de simplicium medicamentorum facultatibus (Strasbourg, Paulli, 1667). Another example is "Tiling. op. 71" or Mathias Tiling's Anchora salutis sacra; seu, De laudano opiato . . . [1671] (HL.2901). Even when the references are at best sketchy, it is sometimes possible to follow what Locke had read. Thus, his earliest medical notebook, MS. e.4, was written while his methods were still imprecise. ${ }^{20}$ On p. 73 , it has a centre heading "Glisson. de Rhachitide." followed by transcripts traceable to pp. 35, 65 and 359 et seq. of the edition in Locke's collection (HL.1271). On p. 225, the heading, "Helm: de Bubone \& Peste" is

\footnotetext{
17 The original of the quotation reads "yet I for honours sake ... shall name him, the Lord Brook. He writing of Episcopacy, ...' (The works of John Milton, New York, Columbia University Press, 1931, vol. 4, p. 346). Examples of "C:" are in MSS. f.14, pp. 1,9 (note especially the entry, 'Campanella'); f.18, p.22; f.20, pp. 230, 231, 245; d.11, OVu; and throughout Brit. Lib. Add. MS. 32,554.

${ }^{18}$ Kearney, op. cit., note 3 above, p. 146. For Barlow's life, see Dictionary of national biography. For his reading list, see Long (1962-67), op. cit., note 6 above, entry for MS. e.17; Harrison and
}

Laslett (1965), op. cit., note 5 above, pp. 13-14. The manuscript has been edited by A DeJordy and H F Fletcher, 'A library for younger schollers'. Compiled by an English scholar-priest about 1655, Illinois studies in language and literature, vol. 48, Urbana, University of Illinois Press, 1961. Locke copied part of the text in MS. e.17 (see review by P Long, Notes and Queries, 1962, 207: 399-400).

${ }_{19}$ MS. f.14, p.11. DeJordy and Fletcher, op. cit., note 18 above, p. 29.

${ }^{20}$ Dewhurst (1959) op. cit., note 2 above; Meynell (1993), op. cit., note 4 above, p. 255. 


\section{G G Meynell}

followed by extracts from Hippocrates redivivus, part of Tumulus pestis, the last section of Helmont's Opuscula medica inaudita (included in HL.1417).

\section{The Catalogue of Locke's Library}

The fullest record of Locke's books is the catalogue he made in a bulky folio known as "Hyde" (HL.1539a). This is a copy of the Bodleian Library catalogue edited by Thomas Hyde (Oxford, 1674) which had been bound with interleaved blank sheets. ${ }^{21}$ When one of Locke's books was already in the Bodleian collection, he worked from the printed entry; otherwise, he wrote a new entry on the facing blank page. As a result, Locke added to rather than altered what he found in Hyde and so inevitably followed Bodleian rules. Boyle's Rarefaction of the air (HL.472) has four parts (HL.416-19) and today is counted as one entry but in the Bodleian catalogue (and in Locke's), each part was entered separately. ${ }^{22}$ Another example is the book by Estienne (Paris, 1567. HL.1954) noted in Figure 1. On the other hand, Locke sometimes combined potentially independent titles as in quoting the separate parts of Sennert's Opera omnia (HL.2617) or Helmont's Ortus medicinae (HL.1417). Each made one catalogue entry although Locke referred to the constituent books individually. ${ }^{23}$ Other features of the catalogue also come from the way in which Hyde was laid out. ${ }^{24}$

\section{Locke's Reading}

As a first step in preparing the database, all the titles in Hyde which appeared to have any relevance to medicine were entered. These included not only obvious medical texts but also books on chemistry which were often concerned with the preparation of chemical remedies like "Sal viperis". 25 More titles were added as successive notebooks were examined, such as books on botany, required for identifying simples, and travel books, read for their details of foreign customs. ${ }^{26} \mathrm{~A}$ miscellaneous group included titles like Bernier, Abrégé de la philosophie de Gassendi (HL.283), Journal des scavans (HL.1589) and Redi, Experimenti circa generationem insectorum (HL.2454). In its final form, the database contained 1,086 records. Given the variety of ways in which the records can be sorted according to the user, what follows here is limited to some examples of what is possible. Thus, it was clear that the medical books quoted in the notebooks included

\footnotetext{
${ }^{21}$ Harrison and Laslett (1965), op. cit., note 5 above, pp. 30-42.

22 British Library catalogue of printed books, shelf-mark 535.b.15. Wing B3985. The corresponding page in Hyde is shown in Harrison and Laslett, Plate 4.

${ }^{23}$ A typical reference to Sennert is "Sennert pr. [Practicae] 1.4. p.3. s.5. c.1. p.716. 56" (MS. d.11, GAi) and any reference of the form "Sennert ... 56" is likewise to his collected works, not to an individual book. Helmont's Ortus medicinae has 114 chapters which Locke always abbreviated, e.g., "Helmont lun. trib. p.584. 52" is Lunare tributum or chapter 10 of the Supplementum.
}

\footnotetext{
24 The Bodleian placed Basil Valentinus at " $V$ " not "B", and "L'Estrange" is at "Estrange". Side headings in Harrison and Laslett like 'Edicts', 'Letters' and 'Trinitas' originate from printed centre headings in Hyde.

${ }^{25}$ Locke attended two classes on the preparation of chemical remedies which were held in Oxford by Peter Stahl in 1663 and 1666 (Meynell, op. cit., note 12 above).

26. For Locke's herbarium, see MSS. b.7 and c.41; and J W Gough, 'John Locke's herbarium', Bodleian Libr. Rec., 1962-67, 7: 42-6.
} 


\section{A Database for John Locke's Medical Notebooks}

proportionately fewer books than Hyde which had been printed in Britain and more from continental countries like Germany, Switzerland, Italy and Denmark. And that the latter arose from the preponderance of books by Rasmus and Thomas Bartholin. ${ }^{27}$

The notebooks examined here are described in Table 1 . They include all those likely to be of medical importance, thanks to Locke's usual practice, discussed later, of reserving each notebook for a specific topic. ${ }^{28}$ The number of identifiable titles differs very markedly from one notebook to another. MS. f.17 has 279 because it includes a long list of books Locke left in the care of his friend, James Tyrrell, whereas MS. f.21 has only two because it is a shorthand version of clinical notes by Locke and Sydenham.

Table 1

Summary of records in the database

Classified as:

Total records:

Number from Hyde:

$\begin{array}{cc}\text { in } & \text { found } \\ \text { database } & \text { in MSS. }\end{array}$

Botany

Chemistry

Medicine

Travel

Miscellaneous

Total:

as \%:

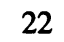

166

622

65

211

1086

(100\%)
21

116

485

65

139

826

$(76 \%)$ $\begin{array}{cc}\text { in } & \text { found } \\ \text { database } & \text { in MSS. }\end{array}$

$\begin{array}{rr}13 & 12 \\ 117 & 67 \\ 461 & 324 \\ 44 & 44 \\ 176 & 104\end{array}$

811

(75\%)
551

"Found": mentioned in one or more notebooks; comprises different types of entry which can be selected individually. Thus, in the third column, the 485 medical records found included 234 citations, 316 entries giving the title in full, 32 with an index, 5 with a page-list, 59 where a book was included in a packing list, 84 where it was bought, and 55 where it was lent.

For the category, "Travel", the numbers shown in the second and third columns are equal because travel books were only added to the database after being found in a notebook. For the other categories, plausible records in Hyde were copied to the database initially but only some of them were subsequently found in the notebooks (e.g. 324/461 in the case of medicine).

\footnotetext{
27 See Harrison and Laslett (1965), op. cit., note 5 above, Table 3 . The difference is evident whether all the titles are considered or only those medical works whose texts are quoted in the notebooks. The percentages are as follows (those from Harrison and Laslett are in brackets): Britain, $16.7 \%(45 \%)$; Netherlands, $21.6 \%$ (19.6\%); France, $13.5 \%$ (16.9\%); Germany, Poland etc., 30.6\% (9.8\%), Switzerland, 5.0\% (3.9\%); Italy, 5.9\% (2.9\%); and Denmark, $2.3 \%$ (0.4\%).
}

\footnotetext{
28 The MSS. of Table 2 are almost entirely distinct from those listed by H A S Schankula, 'A summary catalogue of the philosophical manuscript papers of John Locke', Bodleian Libr. Rec., 1973-78, 9: 24-34, 81-2. Locke also made two lists of authors not considered here which appear to be memoranda, not lists of what he owned or had read (MS. f.47 with over 2,000 names. Public Record Office PRO/30/24/47/30, fol.42-3).
} 


\section{G G Meynell}

The dates of imprints in a given notebook are never identical and may differ very considerably, as shown by the earliest and latest dates given by Long. ${ }^{29}$ The distribution of dates is always markedly skewed to the right as in Figure 1. Although most of the imprints in a given notebook fall within 1650-90, a minority are earlier and may go back to the fifteenth century while, at the other extreme, no title will be later than 1704 , the year of Locke's death.

\section{Books not Traced}

What stands out is that of the 461 medical titles from Hyde, only 324 were traced in the notebooks; and of the 117 chemical titles, only 67 were found. ${ }^{30}$ Thus, of the total 578 medical and chemical titles, only 391 or $68 \%$ seem to have been read by Locke (Table 2). The fact that a book is listed in his library catalogue is clearly no guarantee that it was ever used. Nor, despite Locke's interest in medicine, is there any sign that he took up any of Barlow's recommendations "For those who intend Physick" which included worthwhile books like Castelli's Lexicon medicum, Celsus' De medicina, Estienne's Dictionarium medicum, Gorris' Definitionum medicarum libri XXIIII and Lubin's Epistolae Hippocratis. ${ }^{31}$ Conceivably, by the time Locke turned to medicine, he immediately adopted the experimental approach of his Christ Church friends, Richard Lower and Nathaniel Hodges, and passed over Barlow's suggestions for classical medicine. ${ }^{32}$

\footnotetext{
${ }^{29}$ Long, op. cit., note 6 above. The range is unreliable as an index of the imprints in each notebook because it is grossly inflated by an early volume (which also decreases the mean). The median year is more representative of the imprints in a given notebook.

30 The books present in Hyde but not found in the notebooks comprise:

Medicine: HL.15, 27, 79, 80a, 111, 129, 161, 179, $194,200,216,218,220,221 d, 257,265,298$ a, 349a, $349 \mathrm{~b}, 385,394,399,406,440,459,460,487,488$, $496,497,503 \mathrm{a}, 614 \mathrm{c}, 616,647,654 \mathrm{a}, 668,669,728$, $729,731,741,742 \mathrm{a}, 748,749,750,760,794,805$, 806,845 b, 846, 847, 964, 973a, 1118, 1149, 1183, $1222,1222 \mathrm{a}, 1222 \mathrm{~b}, 1238,1249,1276,1302,1320$, $1365,1383 a, 1397,1398$ a, 1414, 1438, 1442, 1453, $1457,1457 \mathrm{a}, 1466 \mathrm{~b}, 1487 \mathrm{a}, 1578,1584,1585,1627$, $1630,1650 \mathrm{a}, 1660,1711,1740,1815,1890,1892$, $1893,1899,1911,1940,1985,1986,2056,2066$, $2118,2138,2194,2298,2304,2316,2317,2318$, $2319,2320,2321,2322,2323,2324,2511,2533$, 2598, 2600a, 2616b, 2619, 2624, 2625, 2633a, 2640, $2662,2663,2664,2698,2751$ a, 2754, 2811, 2812, $2813,2816 \mathrm{a}, 2817 \mathrm{c}, 2956,2957,2976,3031$ and 3169.

Chemistry: HL.37, 50, 128, 131a, 155, 193, 214a, 221b, 252, 456, 558, 558a, 704, 1031a, 1158, 1226, $1255,1256,1257,1258,1259,1260,1261,1262$, $1263,1264,1265,1266,1267,1268,1269,1270$, $1577,1647,1714,1833,1938,1999,2103,2105$, 2454, 2601c, 2818, 2958a, 3032, 3034, 3036, 3038, 3041 and 3131.

Botany: HL.2692.

Miscellaneous: HL.39, 54, 55, 56, 57, 117, 166,
}

$170,290,360,395,405,414,416,417,418,419$, $420,421,422,423,425,426,427,428,429,430$, $431,432,433,434,435,436,437,438,441,442$, $443,445,446,448,449,450,451,452,454,455$, $458,461,463,464,470,471,472,473,562 \mathrm{a}, 563$, $564,565,809,1246,1360,1646,1707,1708,1962$, $1967,2115,2189,2305,2452$, and 2809.

${ }^{31}$ DeJordy and Fletcher, op. cit., note 18 above, pp. 9, 13.

32 Many of the entries in the early notebooks, MS. e.4 and Brit. Lib. Add. MS. 32,554, end with "RL" or "Hodges". Locke and his friends may have been exceptional in Christ Church which is said to resisted innovation in the seventeenth century (Kearney, op. cit., note 3 above, pp. 120, 123, 147, 164; E G W Bill, Education at Christ Church Oxford, 1660-1800, Oxford, Clarendon Press, 1988, pp. 35, 196). However, in 1659 , an anonymous pamphlet, possibly a satire by Stubbe not to be taken at its face value, proposed a wholesale reorganization of the college, including abolition of the Dean and Canons and establishment of new professorships in subjects like "Des Cartes Philosophy", "Gassendus's Philosophy", physic and anatomy, with "a Chymist for experiments and promoting of Medicines" (Thomason Tract 29 June 1659. C Webster, The great instauration: science, medicine and reform, 1626-1660, London, Duckworth, 1975 , p. 175). Galen's absence from the notebooks is understandable but not that of Hippocrates whose detailed observations on his patients should have been acceptable to Locke (the only quotations from Hippocrates appear to be in MS. d.11, VVu, and in Brit. Lib. Add. MS. 32,554, p. 72). 
Table 2

Details of MSS. Locke

\begin{tabular}{|c|c|c|c|c|c|c|c|c|}
\hline MS. & $\begin{array}{l}\text { Total } \\
\text { titles } 1\end{array}$ & $\begin{array}{l}\text { No. not } \\
\text { in Hyde }\end{array}$ & MS. & $\begin{array}{l}\text { Total } \\
\text { titles }\end{array}$ & $\begin{array}{l}\text { No. not } \\
\text { in Hyde }\end{array}$ & MS. & $\begin{array}{l}\text { Total } \\
\text { titles }\end{array}$ & $\begin{array}{l}\text { No. not } \\
\text { in Hyde }\end{array}$ \\
\hline$A^{2}$ & 118 & 66 & f. 3 & 17 & 1 & f. 18 & 6 & 2 \\
\hline $\mathrm{B}^{3}$ & 5 & 1 & f. 4 & 19 & 3 & f. $19^{10}$ & 76 & 31 \\
\hline $\mathrm{C}^{4}$ & 11 & 1 & f. 5 & 12 & 1 & f. 20 & 12 & 4 \\
\hline c. $29^{5}$ & 8 & 0 & f. 6 & 6 & 0 & f. $21^{11}$ & 2 & 1 \\
\hline c. .33 & 31 & 3 & f. 7 & 11 & 6 & f. 22 & 21 & 0 \\
\hline c. 42 & 11 & 0 & f. $8^{7}$ & 132 & 31 & f. 23 & 6 & 0 \\
\hline d.9 & 140 & 45 & f. 9 & 12 & 3 & f. 24 & 39 & 14 \\
\hline d.11 & 165 & 58 & f. $10^{8}$ & 117 & 10 & f. 25 & 20 & 13 \\
\hline e. 4 & 21 & 8 & f. 14 & 41 & 16 & f. 26 & 7 & 2 \\
\hline$f .1^{6}$ & 11 & 1 & f. 15 & 3 & 2 & f. 27 & 55 & 24 \\
\hline \multirow[t]{2}{*}{ f. 2} & 11 & 0 & f. $17^{9}$ & 279 & 16 & f. 28 & 37 & 6 \\
\hline & & & & & & f. 29 & 21 & 1 \\
\hline
\end{tabular}

Notes:

${ }^{1}$ Total: total number of titles occurring at least once.

${ }^{2}$ British Library Additional MS. 32,554; Adversaria 2 (J R Milton, 'Locke's Adversaria', The Locke Newsletter, 1987, no. 18, pp. 63-74).

${ }^{3}$ Brit. Lib. Add. MS. 46,470.

${ }^{4}$ Brit. Lib. Add. MS. 15,642, the diary for 1679.

${ }^{5} \mathrm{~A}$ collection of miscellaneous papers, including indexes of eight books, possibly from a disbound paperbook; drafts with Sydenham (Dewhurst, 1966; Meynell, 1991); and an early version of Sydenham's Processus integri (G G Meynell, A vindication of Sydenham's Processus integri. An early draft founded on his 'Medical observations' (MS.572), Winterdown Books, Folkestone, 1991).

${ }^{6}$ Bodl. MSS. Locke f.1-f.10 are diaries for the period 12 November 1675-24 October 1704 (but see also note 4 above).

${ }^{7}$ Includes a long list of books apparently bought abroad.

${ }^{8}$ Includes many books lent by Locke to David Thomas.

${ }^{9}$ Includes a long list of books cared for by James Tyrrell, 1691.

${ }^{10}$ See G Meynell, 'Locke's medical notebook, Adversaria 4', The Locke Newsletter, 1994, no. 25, pp. 85-6.

${ }^{11}$ Copies of essays written by or with Sydenham (for detail, see Meynell (1993), op. cit., note 4, Figure 2).

The books not traced, and which were presumably not read, vary greatly in significance. Some have no lasting importance such as $A$ collection of many curious medicinal observations . . (HL.161) or Marloe's Letters to a sick friend (HL.1911). Others, on the other hand, concern discoveries that are now regarded as momentous, such as Leeuwenhoek's book (HL.1707), Papin's A new digester, a precursor of the autoclave (HL.2189) and Acton's critique of Denis' experiments with blood transfusion in humans, then very much under discussion (HL.2976). More obvious omissions are Barbeyrac's Traités nouveaux de médecine (HL.200) although he and Locke were acquainted; Borelli, 


\section{G G Meynell}

De vi percussionis (HL.394); Le Clerc, Histoire de la médecine (HL.750); Le Clerc and Manget, Bibliotheca anatomica (HL.749); Harvey, Exercitationes anatomicae (HL.1397); and Paré's collected works (HL.2194), all of which are listed in Hyde but are not cited in the notebooks.

What is even more surprising is the absence of notes on two authors whose books are prominently represented in Hyde. The first is Glauber with 17 titles (HL.1254-1270) of which 16 do not appear to have been mentioned: the exception is his Furni novi philosophici (HL.1259) which is cited with three other authors on the preparation of "Mercurius philosophorum". ${ }^{33}$ The second is Boyle with 64 titles of which only 11 are cited in the notebooks. ${ }^{34}$ Disregarding four which are theological (HL.450, 452, 454, 455), some of the remaining 49 books include sections of undeniable medical interest which incidentally bear on medical questions Locke studied with Thomas Sydenham with whom he was closely associated after moving to London in 1667. One is how "insalubrity of the air" was related to the onset of plague. This is a major topic in Section V of Sydenham's Methodus (2nd edition, London, Crook, 1668) which appeared after he and Locke had become acquainted and which may indeed have been written with Locke's help. ${ }^{35}$ Another is the rôle of "Nature" in the cure of disease, a theme of Sydenham's books which was also discussed by Boyle. ${ }^{36}$

\section{Books Cited}

Of the books Locke did read, those he rated most highly depends on how they are judged. Locke himself sometimes graded books (and treatments copied from others) by placing against his entry a bar with 1-3 dots placed above or below. He evidently thought very highly of Wepfer's toxicological classic, Cicutae aquaticae historia (HL.3134) and Blegny's L'art de guérir les maladies vénériennes (HL.349), which were each awarded three dots above (Newton's Principia, HL.2083, was given only two). On the other hand, Nymann's Dissertatio de vita foetus in utero (Wittenberg, Helwig, 1628) and Chardin's Journal . . . en Perse (HL.664a) were given one and two dots below the bar, respectively. ${ }^{37}$

A reasonable criterion might seem to be the number of notebooks in which a given title is mentioned but this is meaningless here because of the way in which Locke worked. He did not have favourite books to which he referred over and over again throughout all the

${ }^{33}$ MS. f. 25, p. 270. A packing list has "Glauber 4 vol. 80 " (MS. f.10, p. 23) which are presumably the four volumes in the library catalogue (f.16, fol.113a) with the same shelf marks as HL.1254, Pharmacopoea spagyrica. MS. e.4, p. 42, quotes "Glaub" on the lethal vapour emitted by an angry toad.

${ }^{34}$ A book by Boyle absent from Hyde but frequently cited in MS. f.14 is Some considerations touching the style of the H. Scriptures, London, Herringman, 1661.

${ }^{35}$ See Boyle's An experimental discourse annexed to An essay of the great effects of even languid and unheeded motion (HL.445). G Meynell, 'Sydenham, Locke and Sydenham's De peste sive febre pestilentiali', Med. Hist., 1993, 37: 330-2. An essay on plague in Locke's writing is in the collection, 'Medical Observations', written with Sydenham (Meynell, 1991, op. cit., note 11 above, pp. 33-45).

${ }^{36}$ See Boyle's A free enquiry into the vul [g]arly received notion of Nature (HL.470). M Neuburger, 'An historical survey of the concept of Nature from a medical viewpoint', Isis, 1944, 35: 16-28. For a general account of Sydenham's view of medicine, see Meynell (1988), op. cit., note 4 above, $\$ 11$, pp. 43-55.

${ }^{37}$ Harrison and Laslett (1965), op. cit., note 5 above, p. 40. For books, see amongst many examples, MS. f.8, pp. 38-42. For passages within books, see the indexes in MSS. c. 33 and d.11. 


\section{A Database for John Locke's Medical Notebooks}

notebooks. Instead, he generally mentioned a book frequently in one notebook but not in others, as if he allotted each notebook to one topic and its literature; and when that was finished, he moved on to the next notebook. Thus, of the 18 authors and 9 notebooks listed in Table 3, nine authors were quoted in only one notebook each (e.g. Velthusius); six authors were quoted in two (e.g. Ingrassia); leaving only three authors quoted in more than two notebooks (and each of these three is found predominantly in one notebook each: e.g. Helmont in MS. d.9 and Sennert in f.18).

Table 3

Non-random occurrence of authors amongst MSS. Locke

\begin{tabular}{|c|c|c|c|c|c|c|c|c|c|c|}
\hline Author & H. \& L. & d.9 & d.11 & f. 18 & f. 19 & f. 20 & f. 21 & f. 22 & f. 24 & f. 25 \\
\hline Helmont & 1417 & 18 & 2 & 0 & 5 & 0 & 0 & 1 & 5 & 1 \\
\hline Velschius & 3062 & 28 & 0 & 0 & 2 & 0 & 0 & 0 & 2 & 0 \\
\hline Sennert & 2617 & 2 & 69 & 196 & 0 & 0 & $? 31$ & 0 & 0 & 1 \\
\hline Velthusius & $3063 \mathrm{~g}$ & 0 & 34 & 0 & 0 & 0 & 0 & 0 & 0 & 0 \\
\hline Wepfer ${ }^{1}$ & 3135 & 0 & 20 & 0 & 0 & 0 & 0 & 0 & 0 & 0 \\
\hline Ingrassia & 1547 & 0 & 1 & 35 & 0 & 0 & 0 & 0 & 0 & 0 \\
\hline Ligon $^{2}$ & - & 1 & 0 & 0 & 17 & 0 & 0 & 0 & 0 & 0 \\
\hline Paulli $^{3}$ & - & 0 & 11 & 0 & 84 & 0 & 0 & 0 & 0 & 0 \\
\hline Schott $^{4}$ & - & 0 & 1 & 0 & 23 & 0 & 0 & 0 & 0 & 0 \\
\hline Willis 5 & - & 0 & 0 & 0 & L & 0 & 0 & 0 & 0 & 0 \\
\hline Fuchs & $1198 \mathrm{a}$ & 0 & 0 & 0 & 0 & L & 0 & 0 & 0 & 0 \\
\hline Harvey & 1398 & 0 & 0 & 0 & 0 & $\mathbf{L}$ & 0 & 0 & 0 & 0 \\
\hline Petronius & 2274 & 0 & 0 & 0 & 0 & $\mathbf{L}$ & 0 & 0 & 0 & 0 \\
\hline Plater & 2331 & 3 & 0 & 0 & 0 & 0 & 0 & $\mathbf{L}$ & 0 & 0 \\
\hline Riverius & 2487 & 0 & 0 & 0 & 2 & 0 & 0 & $\mathbf{L}$ & 0 & 0 \\
\hline Wepfer ${ }^{6}$ & 3134 & 0 & 0 & 0 & 0 & 0 & 0 & 0 & 53 & 0 \\
\hline Cellarius ${ }^{7}$ & - & 0 & 0 & 0 & 0 & 0 & 0 & 0 & 0 & 38 \\
\hline Dorneus $^{8}$ & - & 0 & 0 & 0 & 0 & 0 & 0 & 0 & 0 & 13 \\
\hline
\end{tabular}

The imprint cited may differ from notebook to notebook, as shown in its record: e.g., HL.3062 is the 1657 ed. but MS.d.9, p. 13, gives the date as 1668 .

Short titles:

${ }^{1}$ Observationes ... apoplexia.

${ }^{2} A$ true and exact history of . . Barbados.

${ }^{3}$ Quadripartitum botanicum.

${ }^{4}$ Magia universalis.

${ }^{5}$ Locke's notes on Willis's lectures (see Dewhurst (1980), op. cit., note 2 above).

${ }^{6}$ Cicutae aquaticae.

${ }^{7}$ Harmonia macrocosmica.

${ }^{8}$ Fasciculus Paracelsicae medicinae.

L: Few but lengthy extracts. 


\section{G G Meynell}

Not all the books Locke used were by famous authors. The diary for 1679 is filled with references to a book not in Hyde, and today largely overlooked, which Locke and many others evidently found useful: Primerose's De vulgi in medicina erroribus (London, Robinson, 1638 and several later editions). ${ }^{38}$

Yet another criterion for judging what Locke thought of a book is the degree of detail with which he read it. This is apparent from the indexes he made which have been listed here. ${ }^{39}$ In Locke's method, the index is based on the keywords of the entries which led to page numbers. ${ }^{40}$ Another type of index has two facing pages of key words or phrases with their page numbers, such as "Angina sit a sanguine coagulato 108.192" for "Willis. de Febribus. $8^{\circ}$ London.1660 p.376" (HL.3165b). Yet another type is a "page-list", a string of numbers without key words. ${ }^{41}$ All three vary considerably in size, partly because books differ in length. Stubbe's The Indian nectar (HL.2797) has only 184 pages and its index only 11 entries; whereas Paulli's Quadripartitum, a monograph on simples arranged by the four seasons which runs to 690 pages, has an index with over 700 , and a page-list with over 100 , entries.

These medical notebooks may surprise a reader expecting the notes of a man devoted to ideas. Instead of abstractions, they are filled with practical queries and useful recipes. Locke's writing is well known to be characterized by homely images; ${ }^{42}$ like "Pound an Almond, and the clear white Colour will be altered into a dirty one, and the sweet Taste into an oily one", and "the same seething liquors that boil the egg hard make the hen tender". ${ }^{43}$ His down-to-earth entries in the notebooks hardly seem out of character.

38 W R Riddell, 'Dr. James Primrose and his vulgar errours', $N$. Y. State J. Med., 1922, 22: 360-71. N G De Santo, et al., 'Origins of nephrology: the 17 th century. $I$. The fallacies deriving from examination of the urine according to James Primrose', Amer. J. Neph., 1992, 12: 94-101.

${ }^{39}$ Indexes for the following occur as shown:

Medicine: HL.219 (c.33), 221 (c.29), 233 (c.33), 234 (c.33), 235 (c.33), 347 (c.33), 348 (c.33), 349 (c.33), 350 (d.11), 953 (c.29), 1445 (d.11), 1451b (d.11), 1716 (c.33), 1887 (c.33), 1888 (c.33), 2005 (d.11), 2237 (c.29), 2523a (d.11), 2581 (d.11), 2766 (c.29), 2797 (c.29), 2810 (d.9), 2814 (c.29), 2817a (d.11), 2901 (d.9), 3063g (c.29, d.11), 3135 (d.11), 3165a (d.11) and 3165b (c.29). L Septalius, Animadversionum (Padua, Frambottus, 1652. c.33. HL.2618 is a different edition); and T Sydenham, Methodus (London, Crook, 1666. d.11).

Botany: S Paulli, Quadripartitum botanicum (Strasbourg, Paulli, 1667. d.11).

Chemistry: HL.444 (d.11), 1345 (d.9), 2806b (d.11), 3037 (d.11) and 3039 (d.11). Fasciculus Paracelsicae ... Dorneo interprete (Frankfurt am Main, Spies, 1581. d.9).

Travel: HL.286a (c.33), 912 (c.33), 1718 (c.33), 2411 (c.33), 2526 (c.33) and 2528 (c.33).

Miscellaneous: HL.8 (c.33), 332 (c.33), 439

(d.11), 465 (d.11), 1066 (c.33), 1869 (d.11), 2083

(c.33), 2453 (c.33) and 3035 (d.9).

40 Illustrated in Meynell (1993) op. cit., note 4 above, Figure 1.
${ }^{41}$ Page-lists are present in the following notebooks:

Medicine: HL.221c (f.19), 2806b (f.19), 3134 (f.8) and 3138 (f.28). Also for these books not in Hyde: P Grüling, Florilegii Hippocrateo-Galeno-chymici novi (Leipzig, Frommann, 1665. f.19); J F Helvetius, Diribitorium medicum (Amsterdam, Jansson, 1670. d.9).

Botany: S Paulli, Quadripartitum botanicum (Strasbourg, Paulli, 1667. f.19).

Chemistry: G Schultz, Scrutinium cinnabarinum (Halle, Hübner, 1680. f.28) and Dissertatio pharmaceutico-therapeutica (Halle, Hübner, 1678. f.28).

Travel: HL.3138 (f.28). J J Struys, Les voyages ... (Amsterdam, Van Meurs, 1681. f.28).

Page-lists were sometimes written on the endpapers of the books themselves and these are listed by Harrison and Laslett (1965), op. cit., note 5 above, pp. $280-4$.

${ }^{42}$ H Rogers, 'John Locke: his character and philosophy', The Edinburgh Review, or Critical Journal, 1854, 99: 383-454, pp. 398, 402, 406. R Colie, 'The essayist in his Essay', in J W Yolton, (ed.), John Locke: problems and perspectives, Cambridge University Press, 1969.

${ }^{43}$ See J Locke, An essay concerning human understanding, II.viii.20; Dewhurst (1966), op. cit., note 2 above, p. 81 . 


\section{A Database for John Locke's Medical Notebooks}

Locke and his friends were typical supporters of the "moderns" and disparaged "fancy" and "speculative theorems"; and in this respect his interest in writers such as Helmont and Willis may seem anomalous. But his objection was not to speculation as such but to speculation entirely unsupported by experiment and direct observation. ${ }^{44}$ In Helmont, for example, speculation is rampant and, in many accounts of his work, his speculations receive far more prominence than his practical achievements in the laboratory-for a notable exception, see Pagel's essay for the Dictionary of scientific biography-which were presumably what attracted Locke in the first place (Helmont's Ortus medicinae appeared in 1648 shortly before Locke went to Oxford). Willis's lectures in 1663-64 were noted down by Locke and by Lower, and are again full of speculation. But they are also full of Willis's own observations such as "This I have found by experiment" or "When I first saw him". 45

Whether Locke was ever as interested in the theories of the chemists as in their chemical preparations will not be clear until his notes have been analysed but he certainly seems to give far more space to practical chemistry and the preparation of remedies than to speculation. One of the most important practical chemical techniques was heating in a furnace, the subject of Glauber's Furni (HL.1259, which Locke quoted), in which Glauber described five types of furnace followed by numerous preparations made with each. But furnaces raise severe problems in practice like degradation of their brick linings and leakage through poorly sealed containers; and such humdrum though critical points of laboratory technique appear frequently in Locke's notebooks. Many of the details came from his Oxford friends or from Boyle, and might, for example, be the address of a man who sold bottles with reliable glass stoppers, a reservoir and cannula for irrigating wounds, or the construction of a furnace like that used in Boyle's laboratory. ${ }^{46}$

At some point in discussing Locke's books, it is usual to consider how his reading influenced his work, his intellectual development and so on, but to attempt to do so here appears next to impossible, given the number of authors involved. A further difficulty is that what Locke did not mention in his notebooks is surely as interesting as what he did. Two examples have already been noted here, the numerous books by Glauber and by Boyle that are listed in Hyde but not cited by Locke in his notebooks. Another concerns Locke's notes on anatomy, about which both he and Sydenham had severe reservations. ${ }^{47}$ In his manuscript, Anatomia (1668), Locke argued that anatomy was clearly useful to surgeons but was, by its nature, inherently limited in scope because "nature performs all her operations in the body by parts soe minute $\&$ in sensible that I think noe body will ever hope or pretend by the assistance of glasses or any other invention to come to a sight of them". Nevertheless, Locke owned sixteen books by well-known anatomists of the sixteenth and seventeenth centuries, and referred to at least eight of them. ${ }^{48}$ The question arises as to what he took out of these books, a study in itself.

\footnotetext{
44 Locke's manuscript, De arte medica (1669), is largely an attack on scholasticism and on speculation in medicine: Abrams (1967), pp. 86-7; G Meynell, 'Locke as author of Anatomia and De arte medica', The Locke Newsletter, 1994, no. 25: 65-73. See also letters 1556, 1578, 1593 and 2227 in de Beer, op. cit., note 1 above. 88.

45 Dewhurst (1980), op. cit., note 2 above, pp. 55 ,

${ }^{46}$ MSS. f.25, p.267; f.27, pp.2, 56b-57a (irregular
}

pagination). Numerous entries in MSS. c.44, f.15 and f. 19 concern Boyle (Meynell, op. cit., note 12 above, p. 89).

${ }^{47}$ Dewhurst, op. cit., note 2 above, pp. 38-41, attributed Anatomia to Sydenham but the manuscript is almost certainly by Locke (Meynell, op. cit., note 44 above).

${ }^{48}$ Quotations occur from HL.1451a, 1628, 2285, 2331, 2764, 2808 and 2817a. See also HL.107, 1271, 1300,1547 and 1548. 


\section{G G Meynell}

The present records represent only a fraction of the contents of many notebooks. There is, however, the broader question of whether today's collection of notebooks represents only a selection of what once existed. That this may be so is suggested by an entry in Locke's writing. Locke often made his notes in "paperbooks" (presumably, quires of blank sheets sewn together in a cover) which differed in size, ranging from folio down to duodecimo. ${ }^{49}$ Eventually, these were bound properly. On p. 22 of MS. f.16, Locke wrote "Paperbooks. 152.53/ [inserted above the line] ·54.55.56.57.58.59.60 [...] ·79. [gap] ·81", a total of 29 numbers, which presumably indicate 29 separate books. ${ }^{50}$ Only some of these 29 numbers are to be found at the start of Locke's notebooks. ${ }^{51}$ Locke himself may have deliberately destroyed certain notebooks. ${ }^{52}$ The implication is that many of these paperbooks or their bound versions may be missing. Locke's diary for 1679 is missing from the Locke Collection at Oxford but is known to exist because it chanced to enter the British Library. It is to be hoped that other missing notebooks will emerge, once their possible existence is recognized.

${ }^{49}$ Listed in MSS. f.5, pp. 93, 94 (see Harrison and Laslett (1965), op. cit., note 5 above, Appendix I); f.10, pp. 24, 25; f.15, p. 74. Also MS. f.5, p. 18: "1 Fol.paperbook with plants marked JL" (possibly MS. b.7).

${ }^{50}$ Locke used similar strings of numbers when recording his holdings of almanacs and periodicals (MSS. f.4, p. 8; f.9, p. 52; f.28, p. 9). The obvious interpretation is that each number denotes the corresponding year and that the series starts at " 52 " because Locke went to Oxford in 1652, but the real position may be more complicated. He often wrote such numbers at the start of his notebooks but the entries themselves may begin some years either later (as in "Adversaria 60 । Physica": MS. d.9) or earlier (as in MS. f.14 which is marked both 67 and "6": $J$ R Milton, "The date and significance of two of Locke's early manuscripts', The Locke Newsletter, 1988, no. 19: 47-89).

${ }^{51}$ Catalogued in Long, op. cit., note 6 above.

52 See Laslett, op. cit., note 3 above, p. 64 and note therein. 